\title{
RIGHT AND WRONG WAYS OF SEEKING UNITY IN CHRIST: \\ THE CHRISTIAN MISSION IN THE HORIZON OF INTER-CHRISTIAN DIALOGUING
}

Corinna Delkeskamp-Hayes*

\begin{abstract}
Orthodox Christianity in 21st century Europe faces a complex challenge. The ruling post-modernity discounts all claims to a canonical moral and religious vision of human flourishing. Movements favoring ecumenism and interreligious dialogue instead affirm an "enriching diversity" of narratives. Invitations to inter-Christian dialogue issue from those who endorse the most abrupt falling-away from Christianity in Western history, even among Roman Catholics, which happened during the last half-century. This essay argues that involvement in such dialogues implies submitting to Europe's culture of welcoming religious otherness. It compromises Orthodoxy's missionary calling by embedding the Church in the false religious assumptions of the West.

The Orthodox diaspora must both strengthen those within and invite those from outside its fold. Her confession of absolute Truth in Christ conflicts with Europe's commitment to immediate-access-inclusion and undiscerning nondiscrimination. Orthodox participation in ecumenist dialogues, as homage to a liberal pluralism, is often considered unavoidable: It is meant to protect the parishes against charges of fundamentalism and sectarianism. Surveying three examples of such dialogues, this essay highlights the implied agreement with Europe's secular ethos. Such participation undermines what it seeks to protect: parishes' cardinal ministry (Mark 28:19-20) to proclaim the authentic Gospel of Christ in the face of the moral and religious vacuum that remains after the mainline Christianities have betrayed their faith.

With love and patience, the Church must attribute the scandal of disunity to Christians' departure from the mind of the ancient Church. Instead of "one wounded faith" that could be healed through discursive exchanges, Christian disunity manifests a separation from the Church, which calls for conversion. Unity among Christians, as among humans generally, is attainable only through
\end{abstract}

*Editor, „Christian Bioethics - Non ecumenical Studies” in Medical Morality. 
unity with Christ, as achieved within the Orthodox Church.

Keywords: Ecumenism, Truth, post-modernity, equality, recognition, fundamentalism

\section{Introduction: Christian disunity}

Christ wants "all" to be one (Jn. 17:11, 20-23), united in love just like He and the Father (Jn. 11:23, 26). One-ness "in Christ" reconciles man with God, offering the Divine gift of peace. Yet many who claim to be "one" with Christ are still divided. They disagree about how to be "one in Christ," i.e. whether or not as members of any one visible Church, and if so, which Church.

All Christians agree that their disagreements obstruct the mission to which they are called (cf. Mk 28:19-20): How can "all" be invited to become "one with Christ" if Christians remain divided, unreconciled and out of peace with each other?

The so called "ecumenical movement" recommends "dialogues." The ancient Church, after all, had healed Christian disunity through synods. Yet synods were never considered sufficient. Only those agreements (about Church discipline, doctrine, or ritual) would restore a lost unity, which were later recognized as "ecumenical:" Such recognition reflected their adoption into the life of the Church. Only from within the liturgical, ascetical, and charitable practice of a still united people of Christ, as guided by the Holy Spirit, could newly formulated pastoral rules, doctrinal statements and ritual decrees be identified as expressing holy Tradition, rather than deviating. Today, Christian dis-unity runs deeper: There is no more consensus about whether such a Spiritguided people still exists, and where. Unlike the synods of old, today's inter-faith dialogues lack a commonly acknowledged point of reference for assessing their results.

Because of this paradigm change, so this essay argues, dialogues have become ineffective. Failure to notice that change reveals Christians' widespread estrangement from the ancient Church: In focusing on inter-Christian, i.e. horizontal unification, 
rather than on 'vertical' union with Christ, proponents of inter-faith dialoguing fall for a merely ecumenist activism. Their achieved "reconciliations" even hurt the integrity of the Church, and thus "one-ness with Christ" Himself. The scandal of Christian disunity can be removed only if inter-Christian dialoguing is restored to its own missionary context. Christian separation today no longer manifests one wounded Christianity that could be healed by talking. That separation instead divides those who "are the Church" from those "outside", who must be brought in.

The argument begins (II) by looking at the challenges confronting the Christian mission in Western Europe. The Orthodox diaspora here encounters a religious mainstream of distorted, fallenaway Christianities. Their members have internalized the Enlightenment's secular (i.e. subjectivizing, pluralist) commitments. They are embarrassed by the Orthodox proclamation of absolute Truth in Christ and of the Church as His mystical body. Both posttraditional Christians and their non-believing neighbors associate "non-reflective" claims to religious or moral truth with a "fundamentalism" that threatens social peace. This hostile environment, so this essay submits (III), can explain why Orthodox leaders have been willing to partake in the interfaith dialogues staged by their heterodox brothers: Such participation may seem advisable in order to allay mistrust and to improve the public image of the Church. In a further step (IV) some prominent types of such dialogues are examined. The focus here is on their theologically distorted framework commitments. Participation in such dialogues signals implicit consent to the secular ethos permeating these commitments. Orthodox involvement therefore cannot but compromise the witness of the Church. This hurts the missionary work Orthodox leaders had sought to protect. This is why, as the Conclusion (IV) underscores, an Orthodox engagement in ecumenist ventures, if risked at all, should seek to subvert their purpose. Such engagement should use those "dialogues" as a platform for proclaiming Orthodoxy's loving invitation, issued to the separated Christians, into the one true Church. The message should come 
through that unity, reconciliation, and peace among Christians, just as unity, reconciliation, and peace among humans generally, requires unity, reconciliation, and peace with God, as celebrated within the Orthodox Church.

\section{Mission in a post-Christian environment}

Europe is twice post-Christian: Its dominant "secular" ethos rejects the faith that had formed its culture. As committed to human rights, human dignity, and social justice, however, Europe poses as fulfillment of the Christian mission. That mission here reduces to a moral "golden rule," which Europe's social democracies implement on the "higher level" of government-enforced redistribution ${ }^{1}$. For the Orthodox mission, such a setting offers no virgin soil. Locals who still invoke Christ claim to know what they invoke, while the nonbelieving majority claims to know what they reject. There is little curiosity about religious Truth. The very concept has been refashioned: It now denotes contingently adoptable and in the end equally valid perspectives. Any remaining hunger for spiritual experience has been disconnected from "church," since churches seem purely human institutions ${ }^{2}$. Knowledge about the mystical reality of the Church and about Orthodoxy's continued life within that body of Christ is suppressed: The Christian "schism" of the 11th

${ }^{1}$ Ernst Wolfgang Böckenförde, Der säkularisierte Staat, München, SiemensStiftung, 2007, pp. 67f, 72ff.

2 This reduction has ancient roots: When Rome sought to establish her magisterial and juridical authority over the Christian oikomene, it posited the Christ Whom her popes were to represent as "absent". The implied secularizing institutionalization was merely aggravated by the Reformers. Even when Vatican II sought to reconfigure the Roman ecclesiology through "communiontheology," the focus remained on the "Petrine empowerment." Its endorsement inspired no concern for obedience to Christ's teachings, as preserved by the one, unchanged Apostolic, i.e. Orthodox Church. 
century is imputed to some "Greek departure" from Rome ${ }^{3}$. Even more, Orthodoxy's diversely ethnic manifestations are misrepresented as though they repudiated ecclesial unity. As "immigration phenomenon", Orthodoxy appears "non-Western" to those who are kept ignorant of their own millennium of Orthodox roots.

Moreover, secular Europe's robustly individualist ethos disparages any "call to discipleship" as disrespecting autonomy. Repentance, obedience, authority, or chastity have been discredited by centuries of pastoral abuse in quest for power. Europeans who are alive to the isolation such an ethos fosters seek relief in Eastern mysticisms, where the desired wholeness imposes the loss of personhood. Unlike the societies out of which the Apostles called their assemblies, Western Europe today has closed down on transcendence. Its achieved security and comfort has numbed all memory of, and concern about man's eternal vocation. Even the mainline Christians no longer believe in Christ's victory over death, or else take their future bliss for granted. The very terms making up Christ's "good news" have been distorted: "Liberation" today seeks removal of external impediments to the free play of fallen passions; and "love" denotes an emotional quest for a purely human union. A genuinely Christian mission in Western Europe thus faces much "burnt earth".

In such a setting, Orthodox parishes have no alternative but to teach and invite through their lived holiness. Given Europe's tax funded social service network, this witness cannot focus on care for the sick and poor, as was done among pagan Romans. Lived holiness in Western Europe today requires spiritual maturity. Such maturity must be nurtured in the face of immigrants' desire to settle down and integrate themselves in their new, robustly secular work

${ }^{3} \mathrm{Cr}$. Joseph Ratzinger, The spiritual roots of Europe: Yesterday, today, and tomorrow, in Joseph Ratzinger and Marcello Pera (eds.), "Without roots", New York, Basic Books, 2006, p. 55. 
environment. For Orthodox priests, their task imposes special efforts towards both, (1.) differentiation and (2.) separation.

The need for differentiation

Orthodox newcomers to Western Europe today must be protected against mistaking the remnants of a Christian discourse for signs of a shared faith. They must be warned that even where mainline Christian friends and relatives still agree in condemning abortion, same sex marriage and euthanasia, their faith lacks guidance. Protestant authorities have replaced moral orientation by the discussion of options for conscientious choice ${ }^{4}$. Among Roman Catholics, there is widespread doubt about the viability of one canonical Christian conduct, widespread confusion about the hierarchy's moral teaching 5 , and an openly proclaimed refusal to obey even the remaining rules.

In the face of such chaos, Orthodox priests will have to alert their assembly to the destructive consequences resulting from betrayal of the Tradition. They must highlight the dramatic decrease in baptisms, church attendance, vocations to priesthood and monasticism suffered by the mainline Christianities of the West during the last century. They must show how this loss in membership repudiates the social prominence sustained by those bodies' still considerable financial resources and by their disproportionate media presence. Such warnings can strengthen the insight that outside a robustly incarnate pursuit of fasting and prayer, the faith degenerates into an intellectual exercise. Thus reduced, it falls prey to the secular culture's celebration of doubt and uncertainty. Here, only a believer's confession of experienced "difficulties" with his faith is accepted as

${ }^{4}$ See e.g. Kirchenamt der EKD (ed.), Im Geist der Liebe mit dem Leben
umgehen, EKD Texte 71, Hannover. 2002 . 5 See e.g. J. Smits, Exclusive interview: Cardinal burke says confusion spreading among Catholics 'in an alarming way', 2015 https://www.lifesitenews.com/news/exclusive-interview-cardinal-burke-savsconfusion-spreading-among-catholics accessed 10 April. 2015). 
evidence for his sustained personal involvement. In such a culture, "spiritual maturity" reduces to "spiritual mistrust"6.

The need for separation

Orthodox priests must also immunize their faithful against the temptation of insensibly falling into the paths beaten by their heterodox brothers: It was heterodox Christians' yearning for acceptance within their now secularized environment, which led them to identify their Christian commitments with Europe's moral culture. This is why they no longer unconditionally confess the Truth in Christ, and disregard the imminence and non-trivial outcomes of a final judgment. Orthodox priests must warn those in their charge against yearning for such acceptance. They must underscore the risks inherent in too close a fellowship with those whose faith has been secularized (2. Cor. 6:14).

The point is to alert Orthodox believers to the importance of a consciously chosen and maintained cultural otherness. The Church has always affirmed patriarchal authority, both for herself and for the family. She has underscored the headship of husbands over wives after the model of the headship of Christ over the Church. She has affirmed a parental rule that defies the UNESCO's endorsement of the rights of the child ${ }^{7}$, and even includes a (responsively and lovingly applied) corporal punishment (now prohibited in Europe) for children in need of a clear signal. She has sought to nurture a love whose kenotic character defies fallen mankind's absorption in the finite and immanent. All this goes against the grain of Europe's secular ethos.

Maintained cultural otherness reflects the abyss that separates a life directed to holiness from the sentimental religious moralism undergirding the pseudo - Christian quest for social justice. Holiness imposes an at least internally maintained distance from the this-

${ }^{6}$ Unlike the sobriety recommended by the Fathers, such mistrust evinces a mere weakness of will, not the restraint of a burning will.

7 Office of the United Nations' High Commissioner on Human Rights, Convention on the Rights of the Child, 1989, http://www.ohchr.org/EN/ProfessionalInterest/Pages/CRC.aspx. (accessed 17 April 2015), Articles 12-15, 17, 28-9, 31. 
worldly mindset of most Europeans, both Christians and nonChristians. Along with such teaching and the loving pastoral care that embeds it, an Orthodox priest must bear the additional burden of his own witness: Even though in the Western diaspora places of worship are hard to come by and funds notoriously short, heterodox offers of hospitality and support must be received with caution. They come with expectations in view of a "fruitful cooperation" that seeks to foster harmonizing conformity. In order not to compromise their mission, Orthodox priests will refrain from becoming dependent on those whose faith they must in brotherly love identify as misguided.

Only by cultivating such separation and otherness can an Orthodox witness to a rightly oriented Divine glorification render a burnt earth fertile. By maintaining a discernable profile, the Church can alert a misguided and deceived generation to the emptiness of their souls. Only the resolute turn towards holiness in a parish can invite that Divine grace which will touch the heart of non-Orthodox friends, spouses and passersby, inducing them to stay.

Such missionary welcome, of course, must be offered in the local vernacular. Without linguistic adjustment, Orthodox parishioners will fail to missionize their own children, whose home language will be the local one. These children as well must be able to missionize their peers, helping them to experience that Orthodoxy's way of being "not of this world" can make this world look like heaven.

\section{Motives for Orthodox participation in ecumenist dialogues}

This missionary strategy, while hopefully attractive for some, will offend many. Europe's secular framework allows for religious freedom, to be sure. But it contextualizes that freedom by an endorsement of non-discrimination and commitment to social inclusion $^{8}$. The ruling ethos here imposes a tolerance of acceptance,

${ }^{8}$ Treaty of the European Union, Consolidated Version, in "Official Journal" C $326 \quad, \quad 2012, \quad$ Art 2-3, $\quad$ http://eur-lex.europa.eu/legal- 
or of mutual recognition ${ }^{9}$. Any public description of a spirituality as 'perverted', of theological doctrines as 'heretical' or of (legal) actions as 'sinful' violates the code that imposes welcoming religious and world view diversity. Such descriptions are denounced as hate language ${ }^{10}$. 'Perpetrators loose legal employment protection and attract legal sanctions ${ }^{11}$.

Europe's obsession with 'mutual appreciation' reflects the challenge posed by its recent post-secularity. The presence of Islam, with its inherent quest for political implementation, its endorsement of (theologically unconstrained) authority structures ${ }^{12}$, and its tolerance of deadly force for safeguarding moral compliance, threatens Europe's legal culture. Numbed by this threat, the mainstream turns a blind eye to the theological fine print of what it censures. Religious claims to absolute truth are undiscerningly

content/EN/TXT/?uri=CELEX:12012M/TXT (accessed 17 April 2015), and Treaty on the Functioning of the EU, Consolidated version, in "Official Journal" C $326 \quad, 2012$, Pt. II, http://eur-lex.europa.eu/legalcontent/EN/TXT/?uri=CELEX:12012E/TXT (accessed 17 April, 2015). See e.g. legal changes rendering hate speech in view of religious and sexual orientation a crime (L. Christofferson, Denmark, in M. Hill, ed., "Religio and discrimination law in the European Union", Trier, European Consortium for Church and State Research, 2012, p. 100, or also F. Curtit, France, in M. Hill, ed. cit., p. 150).

${ }^{9}$ See discussion and commentaries in Charles Taylor, Multiculturalism and „, The Politics of Recognition“, Amy Gumann (ed.), Princeton, Princeton University Press, 1992.

${ }^{10}$ For further anti-discrimination laws see Miguel R. Blanco, Spain, in M. Hill (ed. cit.), p. $320 \mathrm{f}$.

${ }^{11}$ See e.g. "Christian views 'unacceptable in the workplace', Tribunal hears," in "Christian concern," 2015, http://www.christianconcern.com/ourconcerns/freedom-of-speech/christian-views-unacceptable-in-the-workplacetribunal-hears (accessed 14 April 2015).

${ }^{12}$ On the problems presented by that unlimited character see Cornelia Hayes, Traditionales Glaubensleben in der säkularisierten Gesellschaft: Muslimische Nachbarschaft als Herausforderung für orthodoxe Christen, in Alexander Kariotoglu (ed.) „Islam - Aus orthodoxer Sicht“, vol. 2, Straele, Hagia Sophia, 2013. 
associated with the endorsement of violence, and "violence" applied even to merely psychological pressure. Communal efforts to conform believers' life to the Truth they proclaim are accused of nurturing "parallel societies," where parents disrespect children's autonomy rights. The threat to social peace that comes with Europe's achieved liberalism is claimed to require that believers "reflectively" bracket their faith. The flourishing of a pluralist culture is believed to hinge on members' embrace of the world - view - perspectivism which the Enlightenment proclaimed. Each faith must be confessed as one amongst many equally justified and culturally enriching others. Social cohesion must take precedence over an open and public witness to truth. It is this set of commitments which can explain (1.) why Orthodox leaders may consider it advisable to partake in dialogues and (2.) why the very setup of such dialogues cannot but compromise their own public witness.

The perceived need to engage in dialoguing

In the European Union, traditional believers have it rough. If they violate Europe's ethos, their faith will be publicly denounced as improperly "judgmental", "sectarian" and "fundamentalist". They will be attacked as "male chauvinists" or "homophobes", and their teaching as "black pedagogic". They are exposed to administrative harassment, such as impediments against land purchase, church building, school instruction, access to hospitals and prisons for priests. They may even suffer from "enhanced diversity projects" (such as sale of a publicly owned lot for a mosque right next to a Church $)^{13}$.

Given such challenges, Orthodox leaders have taken to image cultivation by participating in the dialogues, through which their mainline brothers pursue Christian unity. In Europe's secular horizon, dialoguing signals "openness" to others' perspectives and a commitment to mutual tolerance. Even beyond recognition of every one's civil right to endorse, advocate, and practice what he believes, dialogues are to nurture mutual accountability. They are expected to

${ }^{13}$ This happened to the Russian St. Nicholas Church in Frankfurt/Main. 
have a civilizing influence on non-Enlightenment enhanced believers. Participation such events is taken to manifest respect for Europe's culture of welcoming world view diversity.

Orthodox leaders may therefore hope their engagement in ecumenist projects to divert public attention away from the (irremediably counter-cultural) mission of their parishes. Christians, so they might tell themselves, ought to adjust to the mores of their environment. Showing the demanded recognizing respect for religious 'otherness' might even seem a way of rendering to Caesar what is his (Mk. 12:17). Alternatively, such compliance might constitute some kind of refuge from a threatened persecution, as recommended by the Church ${ }^{14}$. Yet there such accommodation comes with integrity risks, to which we now turn.

Integrity risks resulting from the established culture of dialoguing

Dialogues rest on a procedural assumption of equality: They allow each participant a voice and encourage each to respond to others. A more ambitiously substantial human egalitarianism, on the other hand, is core to Europe's liberal ethos. It reflects a belief in humans' native dignity, equally shared by all.

Both kinds of equality inform the democratic functioning in Europe's member states: Citizens are entitled (and encouraged) to participate in the dialogues that shape "public opinion," and thus in the formation of a "societal consensus" claimed to orient political decision making by their representatives. Smaller, and more formally organized dialogues embed this egalitarian proviso in further concerns. Unlike mere conversations, smaller dialogues pursue goals specified in advance. Unlike formal discussions, dialogues pursue an inter-human agenda: Participants are to present what they personally endorse. Along with their knowledge and understanding, they must invest their selves, as framed by what they endorse. Beyond

${ }^{14}$ See (St.) Cyprian of Carthage, The Treatises, trans. E. Wallis, in A. Roberts and J. Donaldson (eds.), "Ante-Nicene Fathers" vol. 5, Peabody, Mass. Hendrickson, 1995, p. 437f. 
discursive exchanges, dialogues seek to nurture human togetherness, and a mutual heart-opening that can facilitate acceptance and agreement. In both their goal-directedness and their personal dimension, dialogues can occupy cultural niches. Unlike the public discourses, dialogues do not have to let their procedural egalitarianism and overlaid by assumptions of substantive equality. Teachers, for example, may engage dialogues in order to activate their students, all the while maintaining their authority. The space they allow for interpersonal openness remains limited.

Yet in ecumenist settings, participants already start out as somehow united through their shared confession of Christ. This presumed "personal" communality makes it easy to confuse dialogues' defining procedural egalitarianism with the socially dominant way in which Europe's ethos affirms substantial equality. Such confusion meets no resistance among mainline Christians because have embraced the secular sense in which humans' equal "dignity" undergirds equal autonomy rights which entitle each to construe and pursue his own vision of human excellence and happiness. Absent any objective point of reference about the human vocation, such recognized autonomy carries a further implication: Those chosen visions are not only recognized as each equally "right" for their choosers, but also (given certain side constraints) as "equally right" in themselves, and entitled to appreciation from everyone. This is why, just as within the public discourse generally, so also within ecumenist dialogues, any disparagement of another's moral or spiritual vision counts as disrespect of that other's dignity. Participants here must not only listen, respond to, and appreciate each other. They must in addition consider all proposed religious and moral visions as equally valid, and preferable only in terms of choosers different cultural progeny, personal history, aspirations, and taste. The very structure of such dialoguing imposes on participants an at least nominal embrace of religious and world view relativism.

Such provisional (or, as one could also say, procedural) relativism still allows for talk about truth. But truth surfaces only as "truth envisioned" by its presenter. Any absolute, exclusive, or 
universal truth claims here reduce to manners of talking, rather than as relevant for the content claimed by others. This limitation is not noticed by the Christians who organize the dialogues: They all agree in linking truth with Christ. They all interpret procedural egalitarianism in terms of humans' shared status as Divine creatures. They all associate substantial egalitarianism with man's Divine gift of freedom, as restored by Christ ( $\mathrm{Rm} .8: 2)$. This common basis is taken to justify hopes that the heart-opening tendency promoted through dialoguing will facilitate further consensus in content, thus establishing "unity in Christ".

The disunity which needs to be overcome, of course, concerns not only doctrine, rituals, morals, and discipline. Disagreement also concerns the extent to and the sense in which such faith-related disunity in fact repudiates unity in Christ, and how such impediments should be removed. The divided Christians thus differ also about goals and methods. Accordingly, "ecumenical" dialogues have taken a variety of shapes during the last hundred years. Some representative samples can illustrate the respective integrity costs inherent in Orthodox participation.

\section{Integrity costs of Orthodox participation in interfaith dialogues}

Different types of dialogues have pursued Christian unity in terms of (1.) universality, (2.) reunion, and (3) unitedness.

1: Dialogues pursuing Christian "universality"

From its beginning, the ecumenical movement (especially the World Council of Churches) focused on the centrality of Christ. Despite doctrinal, pastoral, ecclesial, ritual, and disciplinary diversity, and despite diversely exclusivist, inclusivist or pluralist responses to such diversity, a lowest common denominator unanimity was taken to foster a fellowship aspiring to promote unity. According to the 1997 Common understanding and vision of the 
$\mathrm{WCC}^{15}$, this fellowship, while "no super-church", represents "the universal church of Christ", which, being yet "invisible", is to be rendered visible. Members' founding resolve to "stay together" in this universalizing project is boldly attributed to the Holy Spirit and taken to warrant common worship ${ }^{16}$. Participation in dialogues is obligatory and imposes respect for the "equal value" of and "elements of truth" in the plurality of all member "churches" with their assorted "theological and spiritual" traditions. Such dialogues pursue the task of unification through mutual learning, designed to generate "shared convictions" which are recorded in "convergence texts". Dialogues also promote "reform" within each member church through increased empowerment of women and lay people and develop an ecumenist framework for education in each home country. All members are to abstain from missionary outreach directed against one another.

Taking up the ecumenical Patriarch's remark about the "ecclesiological challenges" involved in such a unification project, the 2006 Final report of the Special Commission on Orthodox Participation in the $\mathrm{WCC}^{17}$, recognizes the discrepancy between the Orthodox and Protestant ecclesiologies. It still endorses further dialoguing in which both sides are "to give an account to each other of what it means to be church". For Orthodox participants, this imposes the "integrity cost" of sending a misguiding public message: It suggests that the meaning of "Church" can be discursively conveyed even to those who, far from offering their willingness to

15 http://www.oikoumene.org/en/resources/documents/assembly/2006-portoalegre/3-preparatory-and-background-documents/common-understanding-andvision-of-the-wcc-cuv (accessed April 17,2015).

${ }^{16}$ On the scandal of Orthodox participation in worship with non-Orthodox see St. Justin of Celje, Orthodox faith and life in Christ (transl. Asterios Gerostergios et al.), Belmont, Mass., Institute for Byzantine and modern Greek Studies, 1994, p. 175.

${ }^{17}$ http://www.oikoumene.org/en/resources/documents/assembly/2006-portoalegre/3-preparatory-and-background-documents/final-report-of-the-specialcommission-on-orthodox-participation-in-the-wcc (accessed April 17, 2015). 
enter into the experience of the Church as the mystical body of $\mathrm{Christ}^{18}$, persevere in their faith in an invisible "universal church", in their pride as representing component parts of that fiction, and in their delusion about the Holy Spirit's endorsement of a worldview that shuts out His sanctifying energies.

2. Dialogues pursuing Christian "reunion"

Dialogues aiming at a "universalizing unification" are dominated by the Protestant (and Anglican) communities. Roman Catholics' quest for unity in Christ, as pursued by the following two types of dialogues, targets mostly the Orthodox. The more ambitious project envisages Eucharistic union as "reunion". The implied integrity costs for Orthodox participants arise from two aspects of the dialogue setup itself (cf. a) and b)) as well as (c) from the conditions under which the envisioned success would have to be implemented.

a) As a first step towards reunion, so it was assumed, certain historically accumulated "impediments" had to be removed. Here the overlay of substantive over procedural equality concerned dialogue partners' ecclesiological status: Both (groups of) representatives were presumed to be equally authorized to reach binding decisions for those whom they represent.

The idea that what hinders Catholic-Orthodox "reunion" presents merely "unfortunate" failings that could be remedied "by decree' had already informed the 1965 Joint Catholic Orthodox declaration co-authored by Pope Paul VI and Ecumenical Patriarch Athonagoras I". Their common "resolve" was considered sufficient to abrogate past mutual excommunications and condemnations. By similarly shared fiat a number of dialogical institutions were founded and charged with the task of "overcoming" both parties' millennium of separation, while also removing the more recent causes for conflict over Uniatism. As an important further step, the 1993

\footnotetext{
${ }^{18}$ In the absurdity of such a message cf. Nikolaos Kabasilas, Das Buch vom Leben in Christus, (transl. Into German G. Hoch), Einsiedeln, Johannes, 1991, p. 79 .

${ }^{19}$ http://w2.vatican.va/content/paul-vi/en/speeches/1965/documents/hf pvi spe 19651207 common-declaration.html (accessed 14 April 2015).
} 
Balamand Declaration ${ }^{20}$ recorded Roman Catholics' willingness to renounce previous policies of encouraging (pressurizing) persecuted Orthodox churches to accept papal rule. The Orthodox partners reciprocated by "recognizing" the independent status of existing Uniate communities.

In order to avoid future conflict, both sides agreed that their respective communities would recognize both side's equal claim to "Apostolic succession" and implied "sacramental validity". Both parties would abstain from "proselytizing" each other's members. Friendly terms of mutual respect were to manifest the Roman Catholic notion of "ecclesial sisterhood". Historiography on both sides was to be revised so as to exorcize any remaining resentment: "Inherited prejudicial readings" were to be obliterated, especially from teaching material used for training future priests.

The problem of Orthodox involvement in such dialogues and signing of declarations lies in the temptation to conceive of one's own entitlement to change the Church and her Tradition after the likeness of the papal (or Pope-backed) entitlements customary among Roman Catholics. Just as the Patriarch had charged ahead like a "sister papal" autocrat in 1964, so the Orthodox ecumenism experts of the Balamand Declaration saw themselves at liberty to repudiate Holy Tradition (i.e. the judgment of the Holy Fathers at ecumenical councils). While the commentary issued by the Assembly of Canonical Orthodox Bishops of the USA still endorses the traditional understanding that "the faithful" will have to adopt what was decreed $^{21}$, no efforts were ever undertaken to even inform the faithful ${ }^{22}$.

20 Joint international commission for the theological dialogue between the Roman Catholic Church and the Orthodox Church, Seventh plenary session, 1993 ,

${ }^{21}$ A Response of the Orthodox/Roman Catholic Consultation in the United States to the Joint International Commission for Theological Dialogue between the Orthodox Church and the Roman Catholic Church Regarding the Balamand

Document,

1994

http://www.assemblyofbishops.org/ministries/dialogue/orthodox-catholic/a- 
By endorsing the dialogues' stated good intentions and invocations of Christ, Orthodox participants have dissociated both from obedient faithfulness to the Holy Tradition informed by Christ. Even more, Orthodox patriarchs and the experts they authorize conform their role in these dialogues to the role through which their Catholic partners manifest their own distorted ecclesiology. In that respect, Orthodox participation compromises the Christian framework for unity with Christ. The declared abstinence from mutual "proselytism", moreover, either renounces an activism which Orthodoxy never condoned, or betrays their mission, i.e. to invite those home who were led astray.

b) A second step towards reunion involves a "process of theological harmonization". Here the overlay of substantive over procedural egalitarianism concerns theological integrity: Both dialogue partners are presumed to represent equally valid doctrines.

The Balamand Declaration indiscriminately calls each side to "take steps" towards bridging, and thus diminishing the "distance" between Roman Catholic and Orthodox teachings. It is assumed that dogmatic disagreements can be worked away through discursive clarifications, mutual translations and conceptual adjustments. Eventually, the one common faith, presumably always preserved intact underneath an artificial overgrowth of mutual misunderstandings, would be uncovered and re-installed. While each side is taken to have gotten its own teachings equally right, at least in some very basic sense, each is also seen as having been equally victimized by errors in view of the rightness of the other ${ }^{23}$. The

response-of-the-orthodoxroman-catholic-consultation-in-the-united-states-tothe-ioint-international-commission-for-theological-dialogue-between-theorthodox-church-and-the-roman-catholic-church-regarding-the-balamanddocument-U.s. -theo.-cons.-1994 (accessed 14 April 2015).

22 Cf. Auxentios of Photiki, "Balamand Explained": First Betrayal, Now Deception, in "Orthodox Tradition" XIV, 1997, pp. 39-42.

${ }^{23}$ See Pope Francis' call to refrain from "apologetics" and "polemics" in interfaith dialogues (Pope Francis concludes Week of Prayer for Christian Unity, in "Vatican Radio" 2015 , 
Orthodox Tradition of exorcizing heterodox deviations from the one conceptually identifiable truth, and of denouncing them as heresies, is here replaced by an accepted diversity that is taken to reflect nothing beyond cultural and linguistic contingencies.

How could Orthodox participants get caught up in such a betrayal? Surely the affective commonality fostered by human company, a common project, shared meals, rest times, all set in a hospitable environment, may foster delusions of spiritual oneness. This might have lured them into following their Roman Catholic partners' lead in considering heresy-talk a thing of the past: After centuries of distorted "exclusivism", Catholics had of course good reason to retract their previous denial of salvation outside of their sacraments. But they fell for the contrary mistake of settling for a "religious otherness" that reduces to different degrees of fullness in access to their truth. This is why they replaced heresy with comparative deficiency. Orthodoxy, in contrast, had never hypothesized about salvation chances for those outside. Forgetting St. Paul's warning (1 Cor. 11:19), they failed to realize that their own spiritual discernment needed no renouncing. In complying with their partners' unfounded supposition of equal validity, the Orthodox failed to offer the loving sacrifice of a healing correction. Their implicit acceptance of a fictional "reconciled diversity" signals consent to the present Pope's disqualifying the quest for the integrity of right glorification as merely man-made uniformism ${ }^{24}$. Orthodox participation in such dialogues repudiates the teaching through which Orthodox priests must protect their faithful against the temptation to feel "at one" with their heterodox environment. Once again, such participation hurts the Christian mission it was designed to protect.

c) But suppose both sides could one day agree to take their shared first millennium as basis for overcoming their dogmatic,

http://en.radiovaticana.va/news/2015/01/25/pope francis concludes week of praver for christian unitv/1119936 (accessed 18 April, 2015).

${ }^{24}$ Ibidem. 
ritual, pastoral and moral differences. Even then, two new difficulties would obstruct the hoped for unification.

A set of dogmatic formulations could be elaborated to which both could subscribe. The Orthodox might read such agreement as Roman Catholics' re-adoption of what the Church has always maintained. But a doubt would remain: Do both sides indeed attach the same meanings to their agreed-upon statements? Theological meaning ultimately derives from the experience of the Divine Self Revelation in Christ and through the Holy Spirit. Such meaning, even if handed down through centuries of academic scholarship, reflects a noetic knowledge which shapes and is fostered by right worship. Without unified worship, even a commonly agreed on vocabulary may reflect merely verbal compromises rather than an achieved unity of faith.

To be sure, Roman Catholics have taken to icons. They sometimes do the liturgies of St. John Chrysostom and St. Basil. Orthodox Christians, on the other hand, have re-discovered their ancient Orthodox Latin Western rite liturgies. Such shared resources might be hoped to promote a unified glorification. Of course, a person's experience of true worship, when received with an open heart, should inspire his desire to be part of the Church in which that worship originates. Precisely such conversion, on the other hand, is what ecumenist dialogues are desgned to impede.

But assuming, even more counterfactually, that Roman Catholic dialogue partners would also adopt the Typikon. Still, the agreed upon teachings and liturgical adjustments would need to be implemented among the Catholic faithful. As deviations from what had been previously proclaimed and practiced, a further step in "doctrinal development" would have to be announced, and supplemented by another liturgical reform. But precisely by affirming the now harmonized faith as such a "further step", the heretical notion of "doctrinal development"" would once again

${ }^{25}$ For recent such "developments" through Vatican II see e.g. Hubert Wolf, Freiheit, 1848 Revolution und katholische Kirche, in Hubert Wolf (ed.) „Freiheit und Katholizismus, “ Ostfildern, Schwabenverlag, 1999, p. 72ff, 79f (with references to the usual arbitrary claims about Spiritual guidance), 83ff. 
separate both parties ${ }^{26}$. Alternatively put: since only a Roman pope could effectively ratify such new renderings as "Spirit-guided", the achieved union would engage a non-Orthodox ecclesiology. The "reunion" would reduce to (a theologically enhanced version, to be sure, of) Uniatism, and thus to yet another betrayal of Orthodoxy.

3. Dialogues pursuing "a united moral voice"

A still further Catholic-Orthodox approach to unity in Christ focuses on cooperation in Christian outreach. Even outside full communion, their considerable moral consensus is believed to sustain a shared public voice, Dialogues here aim at framing strategic alliances for influencing law and public policy making in postChristian societies.

This project reflects Western mainline Christians' attempt at restoring some of the normative authority they had lost through their dis-establishment. Taking themselves to be at risk of reducing to "private sects", they opted for what seemed the only alternative: a "public religion"27. Since Christian guidance no longer enjoyed government backing, it would have to appeal to Europe's "diversely cultural roots" in "Jerusalem, Athens, and Rome". Europe's commitments to human rights, dignity, the separation of church and state, and pluralism would be re-connected with those roots. In this way, Christianity's tried moral wisdom would enrich a robustly secular public discourse. Once a common ground was secured, additional Christian norms and values might become more plausible ${ }^{28}$. Christian guidance would be offered through engagement in "dialogue" with the secular world.

${ }^{26} \mathrm{Cf}$. St. Irenaeus of Lyon, Against Heresies, in Alexander Roberts and James Donaldson (eds.), "Ante-Nicene Fathers", vol. 1., Peabody, Mass., Hendrickson Publishers, 1995, p. 33-38.

${ }^{27}$ Wolf (op.cit.) p.72, see also Joseph Ratzinger, Letter to Marcello Pera, in Joseph Ratzinger and Marcello Pera (ed. cit... p. 120 on a "civil religion that overcomes the boundaries between denominations and gives voice to values that sustain society rather than console the individual".

28 Herminio Rico, John Paul II and the legacy of Dignitatis Humanae, Washington, Georgetown University Press 2002, p. 6, 223, $226 f$. 
Dialoguing, to be sure, has always belonged to the Christian mission. Synagogue assemblies, ready to learn from traveling apostles, were not the rule. Some native pagans (and especially their religious leaders ${ }^{29}$ ) were unprepared to listen. While miracles had offered a head start, the Apostles soon had to work out their welcome. In order to secure an initial interest, they might appeal to what their audiences valued. Even though St. Paul could count on Athenians' ingrained curiosity, he began by commending their piety, as evinced by the altars dotting their roads. He even introduced Christ as the "unknown god" venerated on one of those altars.

Post-Vatican II Roman Catholics have embedded their own missionary dialogues in two kinds of appeals. One invokes the presumed universal accessibility of moral reason, the other the universal human yearning for truth, joy, freedom and love. The first (endorsed by philosophically minded popes up to Benedict XVI) reflects scholasticism's confidence in the ability of reason, even outside of the revealed Divine will, to grasp "the good" which also conforms to that will ${ }^{30}$. Today the prominence of moral prohibitions inherent in this approach (cf. Rico p. 225f, $232 \mathrm{f}, 237$ ) is believed to have alienated believers from their hierarchy. This is why the second appeal (prioritized by Pope Francis) focuses on the inspiring beauty of the Christian life. He combines this proclamation with calls for a "justice" that involves economic equality, the disparagement of markets and objections to "consumerism". He thus affirms what Europe's secular majorities also endorse. If rational arguments for the personhood of fertilized human eggs and the unnaturalness of homosexuality had failed to convince those whose understanding of "moral reason" suggests the opposite, surely, so the assumption goes, a public that agrees with the Pope on politics will also follow his

${ }^{29}$ E.g. Acts 13:8, 19:23.

30 The "non-denominational civil religion" the then Cardinal Ratzinger envisages, while spiritually "fed" by "creative minorities" (of undetermined denominational progeny), will "not conceive of God as a mythical entity but rather as a possibility of reason" (Joseph Ratzinger, Letter to Marcello Pera, in Joseph Ratzinger and Marcello Pera (ed.cit.) p. 129). 
more invitingly offered moral guidance: It is expected to connect the promised truth joy, love, and freedom with the protection of all human life and of traditional families the Pope proclaims. Sadly, of course, secular audiences tend to look for other kinds of truth, joy, love, and freedom: They, for example, will see the abortion of an untimely child as enhancing the mother's freedom to remain "true to herself" by pursuing the career she enjoys while postponing her love for some later child. Obviously, the project of rendering Christian moral guidance palatable by appeal to non-Christians commitments and interests, i.e. without a repentant turn to $\mathrm{God}^{31}$, is not realistic.

Even apart from such failure, Orthodox participation in interfaith dialogues designed to promote moralizing projects ${ }^{32}$ implicates them in a public betrayal of their mission. Orthodoxy has never abandoned the Apostolic teaching about the link between right worship and a rightly oriented conscience, or between a spirit of obedience to the Divine will and proper insight into "the good". It is not the rational philosophy affirmed by scholasticism, which, in deriving some creative agency from creation, reveals true moral principles: Awareness of "a divine transcendence" was, after all, alive in those who turned away by worshiping idols ( $\mathrm{Rm} .1: 21$ ), so that the wrath of God delivered to unclean passions and vain reasonings (Rm. 1:24). "[E]ven of the perversion of the laws", as St. John Chrysostom underscores "it was ungodliness which was the cause"33. By cooperating with heterodox attempts to "morally orient" those outside the faith, Orthodox

${ }^{31}$ Cf. St. Justin of Celje, op. cit., p. 170.

${ }^{32}$ Such participation was recently endorsed during a conference of "Kirche in Not" by Metropolitan Hilarion (Nicht auf Einheit der Kirchen warten, in: „Kirche in Not", 2012, http://www.kirche-in-not.de/aktuellemeldungen/2012/05-30-kirche-in-not-vertreter-bei-metropolit-hilarion-alfejewin-moskau_ (accessed 18 April, 2015). His major focus seems to have been to be freed from the imposition of dialogues in pursuit of Eucharistic union, which he rightly disparaged as unpromising. Yet even strategic political alliances have their integrity costs.

${ }^{33}$ Homilies on the Epistle of Paul to the Romans, in P. Schaff (ed.) "Nicene and Post-Nicene Fathers," $1^{\text {st }}$ series, vol.11, Peabody, Mass., Hendrickson Publishers, $2^{\text {nd }}$. ed., 1995, p. 354. 
representatives obfuscate the fact that only the mysteries can liberate fallen man from his proclivity to $\sin ^{34}$. By participating in "missionary dialogues" the very setup of which, as framed by Vatican II's declaration Dignitatis Humanae, rests on the idea that Christianity itself can be open to and learn from secular movement $\mathrm{s}^{35}$, Orthodox dialogue partners signal their unconcern about the fullness of Truth, which Christ conveyed to His Church.

When Western mainline Christians adopted the Enlightenment's project of extracting a presumed "moral message" from Christianity's "religious trappings", and endorsed that movement's secularized rationalism, they darkened Christianity's genuine "catholic" mission: through worship of praise, gratitude, repentance, and obedience, to offer the created world back to God, so has to allow it to be sanctified. By privatizing their concerns with holiness and disparaging the separation which holiness imposes on those who seek to cooperate with the Divine grace as "sectarian", they secularized their mission, all references to "gospel values" and divine support notwithstanding. When Orthodox dialogue partners invest their authority in support of such a project, they deny the Christ-centered character of their mission to the world.

\footnotetext{
${ }^{34}$ Even a superficial glance at the sacrifices which a legal ban on abortion, stem cell research, homosexual marriages and physician assisted suicide imposes on those whose passions point them to claim their freedom rights in those areas will confirm this. Where else than in a robustly Church anchored life, oriented to eternity, can that Divine love and joy in Christ be experienced, in light of which the ascetic burdens involved in chastity among the unmarried, in distancing oneself from one's distorted sexuality, in renouncing opportunities for powerful medical therapies, and in sustaining the loneliness, suffering, and dependence of old age can be transformed into an liberating experience!

${ }^{35}$ Cf. Rico, op. cit. p. 8, 224, 231, 235. See also Hubert Wolf, , Freiheit, 1848 Revolution und katholische Kirche, in Hubert Wolf (ed.) „Freiheit und Katholizismus", Ostfildern, Schwabenverlag, 1999, pp. 51, 87.
} 


\section{How to protect the Christian mission}

Disunity among those who invoke the name of Christ can be overcome only by Christ through Eucharistic communion. That goal is not furthered by dialogues whose structural framework reflects secular commitments. The implied substantive egalitarianism, not only for humans but also for their religious views, makes it impossible to constrain the procedural egalitarianism inherent in secular dialoguing: When every speaker claims equal time for his self-presentation, the group as a whole can never switch procedures in order to learn from the one who speaks for the Truth. Obsession with substantive equality in dialoguing limits any unifying impact to the horizontal level of psychological communality and output of consensus papers. It leaves no opening for the Holy Spirit's unifying energies to transform the hearts of those who are willing to listen and to turn.

If the egalitarian framework of ecumenist dialogues thus defeat their purpose, can Orthodox involvement be justified? The presumed "Caesar's offering" sends a threefold message of idolatry. It proclaims (\#1) Christian pluralism, (\#2) disregard for the difference between Orthodoxy and heterodoxy, and (\#3) a secularized understanding of "mission". As participants, Orthodox leaders mislead those in their charge. They implicitly repudiate what parish priests must teach, in order to keep their parish together and invite outsiders in: Ecumenist dialoguing hurts the mission it was to protect

Surely, participation in ecumenist projects can obviate such risks by a policy of subversion. This would require insisting that media coverage and press releases make room for a clear and recognizably loving Orthodox statement in which any implicitly misguiding message provided by participation can be repudiated ${ }^{36}$. But of course, such a policy would lead to subsequent non-invitation.

\footnotetext{
${ }^{36}$ Such messages could be inspired the Letter to Pope Francis concerning his past, the abysmal state of papism, and a plea to return to Holy Orthodoxy, written by (Metropolitan) Seraphim of Piraeus and (Metropolitan) Andrew of
} 
The alternative is to abstain. Some Churches (such as the Russian Church Abroad) have followed this maxim. They saw the integrity costs exceeding the expected benefits ${ }^{37}$. They recognized that after liberation from the Turkish Yoke and from Communist oppression, a new, more hidden persecution is under way. This persecution plays on Orthodox believers' un-redeemed craving for societal recognition, for reconciliation with those of other Christian minds, and for man-made peace on earth. This persecution seeks to destroy the faith no longer through deprivation and violence, but through the "bread made of stones" that is offered in the name of an idolized humanity.

Unity among divided Christians is achieved through nothing else but conversion. Cultural diversity is "reconciled" only through union with Christ Who reconciled mankind with His Divine Father. Such union and reconciliation can be achieved only through a missionary outreach to those who already call on Christ. Calling on His name, as Christ made clear (Mt. 7:21), is no guarantee for realized unity: Such oneness requires keeping all that Christ taught. It requires joining his Church, and in protecting her integrity.

\section{References}

1. Auxentios of Photiki, "Balamand Explained": First Betrayal, Now Deception, in "Orthodox Tradition" XIV, 1997, p. 39-42.

2. Blanco, Miguel R., Spain, in M. Hill (ed.), "Religio and discrimination law in the European Union", Trier, European Consortium for Church and State Research, 2012, p. 307-326.

3. Böckenförde, Ernst Wolfgang, Der säkularisierte Staat, München, SiemensStiftung, 2007.

4. Christofferson, L.,Denmark, in M. Hill (ed.), "Religio and discrimination law in the European Union", Trier, European Consortium for Church and State Research, 2012, p.95-110.

Dryinoupolis in 2014, http://orthodoxinfo.com/ecumenism/epistle-to-popefrancis.pdf (accessed 19 April, 2015).

${ }^{37}$ Regardless of many precious friendships, few heterodox dialogue partners ever converted. 
5. Curtit, F., France, in M. Hill (ed.), "Religio and discrimination law in the European Union", Trier, European Consortium for Church and State Research, 2012, p. 145-154.

6. (St.) Cyprian of Carthage, The Treatises, trans. E. Wallis, in A. Roberts and J. Donaldson (eds.), "Ante-Nicene Fathers" vol. 5, Peabody, Mass. Hendrickson, 1995, p. 421-557.

7. Hayes, Cornelia, Traditionales Glaubensleben in der säkularisierten Gesellschaft: Muslimische Nachbarschaft als Herausforderung für orthodoxe Christen, in Alexander Kariotoglu (ed.) „Islam - Aus orthodoxer Sicht," vol. 2, Straele, Hagia Sophia, 2013.,pp. 159-231.

8. (St.) Irenaeus of Lyon, Against Heresies, in Alexander Roberts and James Donaldson (eds.), "Ante-Nicene Fathers", vol. 1., Peabody, Mass., Hendrickson Publishers, 1995, p. 315-567.

9. Kabasilas, Nikolaos, Das Buch vom Leben in Christus, (transl. Into German G. Hoch), Einsiedeln, Johannes, 1991

10. (St.) John Chrysostom, Homilies on the Epistle of Paul to the Romans, in P. Schaff (ed.) "Nicene and Post-Nicene Fathers," 1st series, vol.11, Peabody, Mass., Hendrickson Publishers, 2nd. ed., 1995, p. 335 - 564.

11. (St.) Justin of Celje, Orthodox faith and life in Christ (transl. Asterios Gerostergios et al.), Belmont, Mass., Institute for Byzantine and modern Greek Studies, 1994.

12. Kirchenamt der EKD (ed.), Im Geist der Liebe mit dem Leben umgehen, EKD Texte 71, Hannover. 2002.

13. Ratzinger, Joseph, The spiritual roots of Europe: Yesterday, today, and tomorrow, in Joseph Ratzinger and Marcello Pera (eds.) "Without roots", New York, Basic Books, 2006, p. 51-80.

14. Ratzinger, Joseph, Letter to Marcello Pera, in Joseph Ratzinger and Marcello Pera (eds.), "Without roots", New York, Basic Books, 2006, p. 107-136

15. Rico, Herminio, John Paul II and the legacy of Dignitatis Humanae, Washington, Georgetown University Press 2002.

16. Taylor, Charles, Multiculturalism and „The Politics of Recognition", Amy Gumann (ed.), Princeton, Princeton University Press, 1992

17. Wolf, Hubert, Freiheit, 1848 Revolution und katholische Kirche, in Hubert Wolf (ed.) „Freiheit und Katholizismus,“ Ostfildern. Schwabenverlag, 1999. p.39-70. 


\section{Web sources:}

1. Assembly of Canonical Orthodox Bishops of the USA, A Response of the Orthodox/Roman Catholic Consultation in the United States to the Joint International Commission for Theological Dialogue between the Orthodox Church and the Roman Catholic Church Regarding the Balamand Document, 1994 http:/www.assemblyofbishops.org/ministries/dialogue/orthodox-catholic/aresponse-of-the-orthodoxroman-catholic-consultation-in-the-united-statesto-the-joint-international-commission-for-theological-dialogue-betweenthe-orthodox-church-and-the-roman-catholic-church-regarding-thebalamand-document-u.s.-theo.-cons.-1994 (accessed 14 April 2015).

2. Christian views 'unacceptable in the workplace', Tribunal hears, in "Christian concern", 2015, http://www.christianconcern.com/ourconcerns/freedom-of-speech/christian-views-unacceptable-in-theworkplace-tribunal-hears (accessed 14 April 2015).

3. Joint international commission for the theological dialogue between the Roman Catholic Church and the Orthodox Church, Seventh plenary session (Balamand Declaration),

1993 , http://www.vatican.va/roman_curia/pontifical_councils/chrstuni/ch_orthodo x_docs/rc_pc_chrstuni_doc_19930624_lebanon_en.html (accessed 14 April 2015).

4. Nicht auf Einheit der Kirchen warten, in: „Kirche in Not", 2012 , http://www.kirche-in-not.de/aktuelle-meldungen/2012/05-30-kirche-in-notvertreter-bei-metropolit-hilarion-alfejew-in-moskau_ (accessed 18 April, 2015).

5. Office of the United Nations' High Commissioner on Human Rights, Convention on the Rights of the Child. 1989. http://www.ohchr.org/EN/ProfessionalInterest/Pages/CRC.aspx, (accessed 17 April 2015).

6. (Pope) Paul VI and (Patriarch) Athenagoras I, Joint Catholic Orthodox declaration, $\quad 1965 \quad \mathrm{http} / / / \mathrm{w} 2 . v a t i c a n . v a / c o n t e n t / p a u l-$ vi/en/speeches/1965/documents/hf_p-vi_spe_19651207_commondeclaration.html (accessed 14 April 2015).

7. Pope Francis concludes Week of Prayer for Christian Unity, in "Vatican Radio" 2015 , http://en.radiovaticana.va/news/2015/01/25/pope_francis_concludes_week of_prayer_for_christian_unity/1119936 (accessed 18 April, 2015).

8. (Metropolitan) Seraphim of Piraeus and (Metropolitan) Andrew of Dryinoupolis, A letter to Pope Francis concerning his past, the abysmal 
state of papism, and a plea to return to Holy Orthodoxy, 2014, http://orthodoxinfo.com/ecumenism/epistle-to-pope-francis.pdf (accessed 19 April, 2015).

9. Smits, J., Exclusive interview: Cardinal burke says confusion spreading among Catholics 'in an alarming way', 2015 https://www.lifesitenews.com/news/exclusive-interview-cardinal-burkesays-confusion-spreading-among-catholics accessed 10 April, 2015)

10. Treaty of the European Union, Consolidated Version, in "Official Journal" C 326,2012 , p. 1 -390, http://eur-lex.europa.eu/legalcontent/EN/TXT/?uri=CELEX:12012M/TXT (accessed 17 April 2015).

11. Treaty on the Functioning of the EU, Consolidated version, in "Official Journal" C 326 , 2012, p. 1 - 390, http://eur-lex.europa.eu/legalcontent/EN/TXT/?uri=CELEX:12012E/TXT

12. (accessed 17 April, 2015)

13. WCC (World Council of Churches, ed.), Common understanding and vision of the WCC (CUV), http://www.oikoumene.org/en/resources/documents/assembly/2006-portoalegre/3-preparatory-and-background-documents/common-understandingand-vision-of-the-wcc-cuv (accessed April 17,2015).

14. WCC (ed.), Final report of the Special Commission on Orthodox Participation in the WCC, 2006, http:/www.oikoumene.org/en/resources/documents/assembly/2006-portoalegre/3-preparatory-and-background-documents/final-report-of-thespecial-commission-on-orthodox-participation-in-the-wcc (accessed April 17, 2015). 